\title{
SISTEM PAKAR DIAGNOSA PENYAKIT AYAM PETELUR MENGGUNAKAN METODE CASE BASED REASONING BERBASIS WEB
}

\author{
Zendy Achmad Faisal \\ Program Studi Teknik Informatika S1, Fakultas Teknologi Industri \\ Institut Teknologi Nasional Malang, Jalan Raya Karanglo km 2 Malang, Indonesia \\ zendyachmad32@gmail.com
}

\begin{abstract}
ABSTRAK
Munculnya permasalahan dan penyakit pada ayam ini disinyalir akibat kelalaian peternak yang kurang memperhatikan nutrisi bahan pakan yang diberikan pada ayam peliharaannya. Penyakitpenyakit yang sering menjangkit ayam petelur adalah: Newcastle Disease (ND), Infectious Bronchitis (IB), Gumboro Disease dan Flu. Pada setiap penyakit tersebut memiliki gejala yang hampir sama namun membutuhan penanganan dan tindakan yang bebeda-beda sehingga banyak peternak yang sulit mengidentifikasi penyakit apa yang menjangkit ternak mereka.

Pengumpulan data yang dijadikan bahan pembuatan sistem pakar menggunakan metode case base reasoning ini dilakukan dengan wawancara dengan technical service obat (ahli dalam bidang penanganan penyakit ayam petelur) pada instansi Manunggal Putra Unggas. Dalam tahap ini, berkonsultasi tentang informasi mengenai segala penyakit ayam petelur, gejala penyakit ayam petelur, serta bobot nilai pada setiap gejala yang merupakan tingkat keyakinan dari ahli dalam penyakit ayam petelur. Setelah dilakukan wawancara, maka diperoleh informasi mengenai mengenai nilai bobot dari penyakit dan gejala penyakit ayam yang akan digunakan dalam sistem pakar diagnosis penyakit pada ayam petelur yang diperoleh dari technical service penanganan unggas yaitu Bpk Taufan Rohadie.

Pada jurnal hasil penelitian sosio-economic impact didapatkan pada insutri peternakan ayam yang ada di Indonesia bahwa wabah penyakit ayam pada umumnya menyerang perusahaan peternakan ayam petelur. Sekitar $83 \%$ dari total populasi. Informasi ini mengungkapkan bahwa perusahaan ayam petelur lebih rentan terkena wabah penyakit daripada perusahaan ayam boiler.
\end{abstract}

Kata kunci : Sistem Pakar, Case Base Reasoning, Penyakit Ayam Petelur

\section{PENDAHULUAN}

Usaha peternakan ayam petelur saat ini semakin banyak diminati masyarakat, karena meningkatnya kesadaran masyarakat tentang pentingnya mengkonsumsi telur. Telur merupakan sumber protein hewani yang paling murah dan banyak tersedia. Salah satu faktor penunjang usaha peternakan adalah manajemen kesehatan berupa biosecurity dan penanganan penyakit. Apabila aspek tersebut kurang diperhatikan, maka akan berpengaruh pada turunnya produksi telur dan meningkatnya tingkat mortalitas ayam. Oleh karena itu, untuk dapat mencegah ataupun menangani suatu penyakit diperlukan diagnosa dari para ahli, seperti dokter hewan, ataupun pakar(Shofia Ayu,2017)

Hama dan penyakit pada ayam petelur adalah salah satu masalah yang besar dihadapi peternak - peternak di Indonesia, terutamanya peternak ayam petelur. Hama dan penyakit ini akan menurunkan produktivitas telur dratis. Selain itu, akan mengakibatkan ketidak stabilan hormon dan organ pembentuk telur, sehingga telur akan cacat atau abnormal dan bahkan akan mengakibatkan angka kematian yang sangat tinggi. Pengendalian hama dan penyakit ayam petelur tersebut harus di ambil serius sebelum menjadi penyebaran dan juga mengakibatkan kerugian yang sangat besar saat melakukan budidaya ayam petelur ini. Jika demikian harus segera dengan cara alami maupun dengan kimia, agar tidak terjadinya penurunan produksi pada telur. Sebelum itu dilakukan, sebaiknya mengetahui hama dan penyakit yang sering menyerang pada ayam petelur terlebih dahulu, baru langsung melakukan penangganan dengan tepat.

Dalam usaha meningkatkan kualitas ayam petelur dan mengurangi kematian akibat penyakit ayam petelur, dibutuhkan pakar peternakan yang berpengalaman. Saat ini ketersediaan sumber daya pakar peternakan masih sangat terbatas dan banyak pengetahuan pakar yang hilang akibat kurangnya dokumentasi. Tujuan yang hendak dicapai adalah merancang suatu prototipe sistem penalaran berbasis kasus (Case Base Reasoning) yang dapat digunakan sebagai alat bantu untuk melakukan diagnosa penyakit pada ayam petelur. Pembuatan prototipe sistem ini dilakukan dengan 
menggunakan representasi pengetahuan dilakukan dalam bentuk kasus yang sudah ada. kesimpulan yang diperoleh adalah prototipe system ini dapat mendiagnosa penyakit ayam petelur dengan baik dan hasil analisisnya dapat diterima oleh pakar peternakan maupun pengguna non pakar. Namun sistem ini masih memiliki kekurangan yaitu keterbatasan dalam basis pengetahuannya. Prototipe sistem ini tidak dimaksudkan untuk menggantikan pakar peternakan melainkan sebagai alat bantu dalam mendiagnosa penyakit pada ayam petelur.. Berdasarkan permasalahan di atas maka dibangun sebuah sistem pakar berbasis web dengan judul "Sistem Pakar Diagnosa Penyakit Ayam Petelur Menggunakan Metode Case Based Reasoning Berbasis Web "Dengan adanya website ini diharapkan mempermudah para peternak untuk mengetahui gejala mendapatkan nformasi pengendalian hama/penyakit.

\section{TINJAUAN PUSTAKA}

Berdasarkan penelitian yang dilakukan oleh Rabiah Adawiyah pada tahun 2017 yang berjudul "Case Base Reasoning Untuk Diagnosis Penyakit Demam Berdarah". Hasil pengujian yang telah dilakukan terhadap 54 data uji, menunjukkan bahwa sistem mampu mengenali penyakit tersebut dengan menggunakan nearest neighbor dengan nilai sensitivitas $98.14 \%$ dan akurasi sistem 99.25\%. Berdasarkan hasil pengujian yang diperoleh maka dapat dikatakan bahwa sistem CBR yang dibangun dapat mendiagnosis penyakit akibat virus dengue dengan baik dan benar. Dapat digunakan teknik Indexing dengan metode lain sehingga hasil yang diperoleh nantinya dapat dibandingkan mana yang penggunaanya paling optimal. Pada penelitian selanjutnya, sistem dapat dibangun dalam bentuk website atau aplikasi mobile sehingga pengguna dapat lebih leluasa mengakses sistem kapan saja dan dimana saja.

Berdasarkan penelitian yang dilakukan oleh Tiara Eka dkk pada tahun 2016 yang berjudul "Implementasi Metode Case Base Reaoning Dalam Pemilihan Pestisida Terhadap Hama Padi Sawah Menggunakan Algoritma KNN". Metode case based reasoning dan algoritma knearest neighbor yang diimplementasikan pada sistem ini, dapat melakukan perhitungan similarity antara kasus baru dengan kasus training dengan keakuratan validasi $100 \%$ Perhitungan dilakukan dengan jumlah data training hama sebanyak 261 kasus dan 105 kasus training pestisida. Pada pengujian ketika sistem dibangun hanya dengan melibatkan $80 \%$ data sebagai trainingdan $20 \%$ unseen instances sebagai data testing diperoleh hasil keakuratan verifikasi sebesar 95,83\% yang artinya hamper semua data dapat dikenali.

\subsection{Pengertian Sistem Pakar}

Sistem pakar (expert system) secara umum adalah sistem yang berusaha mengadopsi pengetahuan manusia ke komputer, agar komputer dapat menyelesaikan masalah seperti yang biasa dilakukan oleh para ahli. Atau dengan kata lain sistem pakar adalah sistem yang didesain dan diimplementasikan dengan bantuan bahasa pemrograman tertentu untuk dapat menyelesaikan masalah seperti yang dilakukan oleh para ahli. Diharapkan dengan sistem ini, orang awam dapat menyelesaikan masalah tertentu baik 'sedikit' rumit ataupun rumit sekalipun 'tanpa' bantuan para ahli dalam bidang tersebut. Sedangkan bagi para ahli, sistem ini dapat digunakan sebagai asisten yang berpengalaman. Sistem pakar merupakan cabang dari Artificial Intelligence (AI) yang cukup tua karena sistem ini telah mulai dikembangkan pada pertengahan tahun 1960. Sistem pakar yang muncul pertama kali adalah General-purpose problem solver (GPS) yang dikembangkan oleh Newl dan Simon. Sampai saat ini sudah banyak sistem pakar yang dibuat, seperti MYCIN, DENDRAL, XCON \& XSEL, SOPHIE, Prospector, FOLIO, DELTA, dan sebagainya (Kusumadewi, 2003).

\subsection{Case Base Reasoning}

Penalaran berbasis kasus atau Case Based Reasoning adalah salah satu metode penyelesaian masalah berbasis pengetahuan untuk mempelajari dan memecahkan masalah berdasarkan pengalaman masa lalu. Untuk menghasilkan solusi suatu masalah, harus melakukan beberapa tahap proses dimana proses CBR harus mencari kemiripan kasus baru dengan kasus yang tersimpan, atau ketika ada perubahan terhadap solusi suatu kasus. Tahapan proses yang terjadi dalam CBR dapat dilihat pada Gambar 2. (Mukhamad Said, 2015).

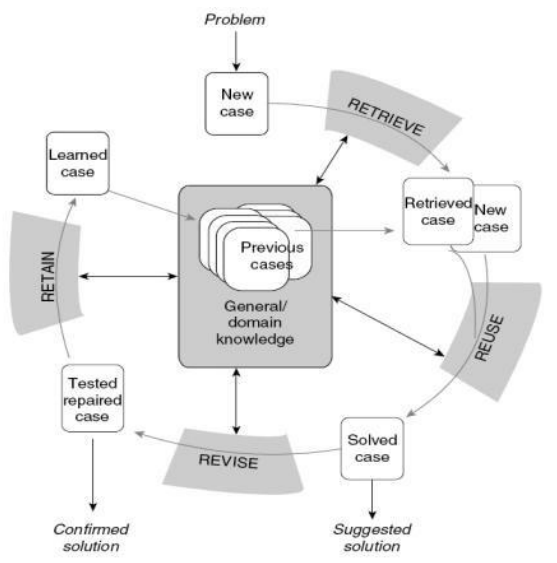


Pada gambar diatas dijelaskan bahwa dalam proses $C B R$ ada dibutuhkan 4 (empat) tahap, yaitu :

1. Retrive : Mendapatkan kasus-kasus yang mirip dibandingkan dengan kumpulan kasuskasus dimasa lalu.Dimulai dengan tahapan mengenali masalah dan berakhir ketika kasus yang ingin dicari solusinya telah ditemukan serupa dengan kasus yang telah ada. Tahapan yang ada pada retrieve ini antara lain :
a. Identifikasi Masalah
b. Memulai Pencocokan
c. Menyeleksi.

2. Reuse : Menggunakan kembali kasus-kasus yang ada dan dicoba untuk menyelesaikan suatu masalah sekarang. Reuse suatu kasus dalam konteks kasus baru terfokus pada dua aspek yaitu : perbedaan antara kasus yang ada dengan kasus yang baru dan bagian mana dari retrieve case yang dapat digunakan pada kasus yang baru. Ada dua cara yang digunakan untuk me-reuse kasus yang telah ada yaitu : reuse solusi dari kasus yang telah ada (transformatial reuse) atau reuse metode kasus yang ada untuk membuat solusi (derivational reuse).

3. Revise : Merubah dan mengadopsi solusi yang ditawarkan jika perlu.terdapat dua tugas utama dari tahapan ini yaitu :

a. Evaluasi Solusi.

Evaluasi solusi adalah bagaimana hasil yang didapatkan setelah membandingkan solusi dengan keadaan yang sebenarnya.Hal ini biasanya tahapan diluar dari sistim ini. Pada tahap evaluasi ini sering memerlukan waktu yang panjang tergantung dari aplikasi apa yang sedang dikembangkan.

b. Memperbaiki Kesalahan

Perbaikan suatu kasus meliputi pengenalan kesalahan dari solusi yang dibuat dan mengambil atau membuat penjelasan tentang kesalahan tersebut

4. Retain : Tetap memakai solusi yang terakhir sebagai bagian dari kasus baru. Pada tahap ini terjadi suatu proses penggabungan dari solusi kasus yang baru yang benar ke knowledge yang telah ada

\subsection{Teknik Similarity}

Merupakan salah satu teknik pendekatan yang dapat menentukan bobot kesamaan dari suatu kasus, sehingga saat kasus itu dianggap cukup mirip maka kasus itu akan menjadi solusi dari permasalahan pengguna, Similarity melakukan analisis perhitungan pembobotan pada setiap kasus yang menjadi solusi, dapat dilihat pada Gambar 2

$$
\text { Similarity }=\frac{S 1 * w 1+S 2 * w 2+\ldots .+S n * w n}{W 1+W 2+\ldots .+W n}
$$

Gambar 2. Cara Mencari Nilai Kesamaan Kasus (Similarity)

Keterangan :

S : Similarity ( Nilai kemiripan ) yaitu 1 (sama ) dan 0 (beda)

W: Weight (bobot)

\section{ANALISIS DAN PERANCANGAN}

Analisis sistem merupakan proses identifikasi dan evaluasi permasalahan yang dibangun sesuai dengan kriteria yang diharapkan. Oleh karena itu aplikasi harus memenuhi kebutuhan yaitu aplikasi bisa digunakan pada semua sistem operasi dan mampu mengimplementasikan perhitungan sesuai metode yang dipakai. Pada bab ini juga akan dijelaskan langkah-langkah perancangan Sistem Pakar Diagnosis Penyakit Ayam Petelur yang ditunjukkan pada Gambar 3.1

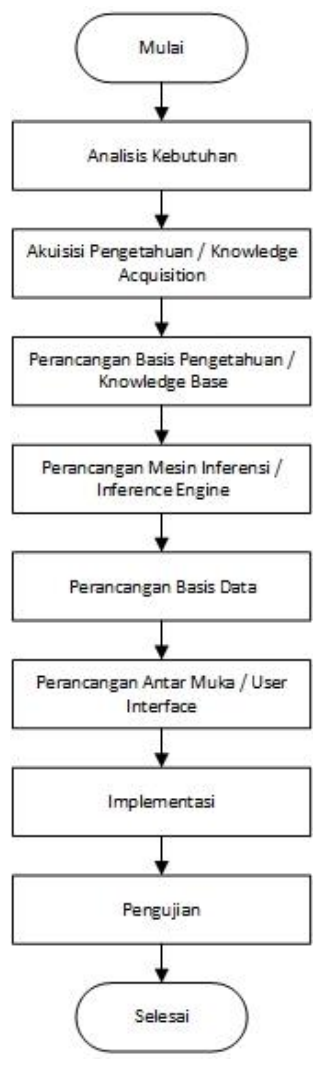

Gambar 3.4 Langkah Perancangan SP diagnosis penyakit ayam petelur 


\subsection{Analisis Kebutuhan Sistem}

Analisis kebutuhan sistem sangat dibutuhkan dalam mendukung kinerja sistem, apakah sistem yang dibuat telah sesuai dengan kebutuhan atau belum karena kebutuhan sistem akan mendukung tercapainya tujuan pembuatan aplikasi.

\subsection{Analisis Sistem}

Dengan adanya sistem pakar untuk mendiagnosa penyakit pada ayam petelur diharapkan dapat membantu para peternak ayam petelur dalam mendiagnosa penyakit. Diagnosa penyakit dilakukan ketika ayam mengalami gejala-gejala berdasarkan basis pengetahuan gejala-gejala penyakit ayam petelur yang terdapat pada sistem. Peternak yang melakukan diagnosa berdasarkan gejala-gejala yang muncul akan diproses oleh aplikasi sistem pakar selanjutnya sistem akan memberikan informasi penyakit dan solusi penanganannya.

\subsection{Analisis Kebutuhan}

Kebutuhan informasi tidak terlepas dalam penelitian ini guna mendukung perancangan sistem yang sesuai dengan penerapan di lapangan. Informasi yang dibutuhkan antara lain seperti informasi mengenai penyakit-penyakit dan gejala serta solusi penangan terhadap penyakit ayam petelur.

Informasi mengenai penyakit ayam petelur diperlukan dalam pengenalan penyakit apa saja yang terdapat pada ayam petelur. Gejala penyakit dibutuhkan untuk mendeteksi gejala-gejala yang mungkin timbul ketika ayam petelur menderita penyakit. Informasi mengenai solusi yaitu bagaimana mengambil solusi penanganan ketika penyakit pada ayam petelur telah terdeteksi berdasarkan hasil diagnosa.

\subsection{Perancangan Sistem}

Perancangan sistem menguraikan bagaimana alur proses input maupun output dari sistem yang akan dihasilkan. Perancangan sistem ini dapat digambarkan melalui diagram aliran data maupun konteks diagram yang akan menggambarkan aliran data terhadap sistem yang dirancang.

\subsection{Konteks Diagram (Diagram Context)}

Diagram konteks digunakan untuk menggambarkan keseluruhan dari sistem yang dirancang. Adapun perancangannya dapat dilihat pada gambar 3.1 berikut :

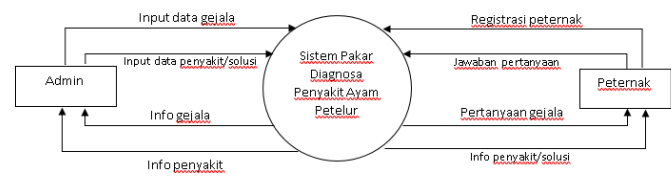

Gambar 3.1 Konteks Diagram Sistem Pakar Penyakit Ayam Petelur

Event list :

1. Peternak melakukan diagnosa ke sistem pakar diagnosa penyakit ayam petelur dan peternak memasukkan jenis gejala yang diderita.

2. Sistem akan memberikan pertanyaan berupa gejala-gejala apa saja yang diderita oleh ayam petelur yang berguna sebagai basis pengetahuan bagi sistem dalam mendiagnosa penyakit.

3. Peternak ayam petelur akan menjawab pertanyaan-pertanyaan yang di ajukan oleh sistem berdasarkan gejala-gejala apa saja yang diderita oleh ayam petelur.

4. Sistem akan memberikan hasil berdasarkan gejala-gejala yang diderita oleh ayam petelur. Hasil berupa data penyakit dan solusi penanganannya.

\subsection{Kebutuhan Fungsional}

Kebutuhan fungsional dari sistem pakar berbasis web ini adalah :

1. Pengguna memilih menu yang diinginkan

2. Pengguna menceklis sejumlah opsi/pilihan dengan cara memilih jawaban yang telah disediakan yang berhubungan dengan Penyakit ayam petelur yang akan di diagnosis.

3. Admin dapat menambah, mengubah, dan menghapus data gejala dan penyakit

4. Admin dapat mengelola informasi penyakit penyakit ayam petelur

\subsection{Kebutuhan Perangkat}

Perangkat lunak yang digunakan dalam pengembangan sistem pakar penyakit ayam petelur adalah :

1. Sistem Operasi : Windows 8.1

2. Local Server : XAMPP v3.2.1.

3. Script Server : PHP.

4. Web Browser : Opera, Google Chrome

5. Sublime Text 3.

\subsection{Basis Pengetahuan}

Basis pengetahuan merupakan tempat penyimpanan pengetahuan yang berupa informasi dari domain aplikasi dan menyediakan untuk sistem. Fakta dan kasus disimpan dalam bentuk database, fakta direpresentasikan dengan 
menetapkan kesesuaian antara representasi internal fakta dengan representasi bahasa alami. kasus ini berisi tentang bagaimana menggunakan pengetahuan untuk memecahkan suatu masalah pada masa lampau. Kasus pada basis pengetahuan direpresentasikan sebagai sekumpulan nilai tingkatan kepercayaan yang akan diuji kebenarannya. Pada rancangan gejala dan penyakit dibawah menjelaskan tabel 3.1 adalah rancangan penyakit yang berisi Kode dan Penyakit yang akan diimplementasikan ke metode Case Base Reasoning

\begin{tabular}{|c|l|}
\hline KODE & \multicolumn{1}{|c|}{ NAMA PENYAKIT AYAM } \\
\hline P01 & Berak kapur(pullorum) \\
\hline P02 & Kolera \\
\hline P03 & $\begin{array}{l}\text { Chronic Respiration } \\
\text { Disease(CDR) atau ngorok }\end{array}$ \\
\hline P04 & Colibacillosis \\
\hline P05 & Flu burung \\
\hline P06 & ND(new castle Disease/tetelo) \\
\hline P07 & Gumboro \\
\hline P08 & Infeksi Bronchitis(IB) \\
\hline P09 & Marek(Visceral Leukosis) \\
\hline P10 & Berak darah(koksidiosis) \\
\hline P11 & Cacingan \\
\hline P12 & $\begin{array}{l}\text { Diptheria avium dan fow1 } \\
\text { pox(cacar unggas) }\end{array}$ \\
\hline P13 & Coryza (snot selesema) \\
\hline P14 & Infectious laringotracheitis (ILT) \\
\hline
\end{tabular}

Pada data Penyakit pada Tabel 3.2 menjelaskan tentang kode dan gejala ayam petelur yang yang akan di implemetasikan ke dalam metode Case Base Reasoning .

\section{HASIL DAN PEMBAHASAN}

\subsection{Halaman Administrator Sistem Pakar}

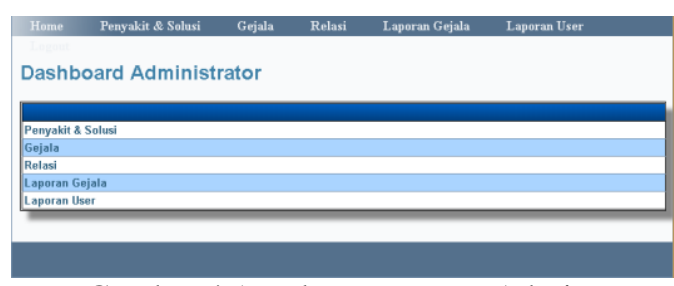

Gambar 4.1 Halaman Utama Admin.

Gambar 4.1 merupakan halaman utama pada admin yang berisi gejala penyakit relasi dan tentang dan dapat mengganti atau menambah data dari pakar.

\begin{tabular}{|c|l|}
\hline KODE & \multicolumn{1}{|c|}{ NAMA GEJALA } \\
\hline G001 & Perubahan warna jengger \\
\hline G002 & Mata menutup \\
\hline G003 & Pembengkakan pada jengger \\
\hline G004 & Mengeleng-gelengkan kepala \\
\hline G005 & Terdapat cairan di mata dan gangguan pernafasan \\
\hline G006 & Rongga mulut mengeluarkan cairan jernih sampai kental \\
\hline G007 & jengger dan kepala menjadi kebiruan \\
\hline G008 & kornea mata keruh \\
\hline G009 & pengeluaran ledir dari hidung \\
\hline G010 & pupil mata berbentuk irregular disertai diare berat \\
\hline G011 & Luka Berwarna putih dan berdarah pada mulut \\
\hline G012 & Mulut berlendir \\
\hline G013 & Sesak nafas adanya lendir berdarah di rongga mulut \\
\hline G014 & Kepala Ditegakkan Dan mulutnya berlendir \\
\hline G015 & Pembekakan pada muka \\
\hline G016 & Badan menunduk \\
\hline G017 & Sayap terkulai \\
\hline G018 & Pantat memutih dan lengket \\
\hline G019 & Pembengkakan serta kelumpuhan pada sayap \\
\hline G020 & Sayap turun \\
\hline G021 & Lumpuh disertai sulit nafas dan diare \\
\hline G022 & Sayap kusam dan terkulai \\
\hline G023 & Menyatunya bulu pada daerah dubur \\
\hline
\end{tabular}

\subsection{Halaman User Sistem Pakar}

Sistem Pakar Diagnosa Penyakit Ayam Petelur Menggunakan Metode Case Based Reasoning (CBR)

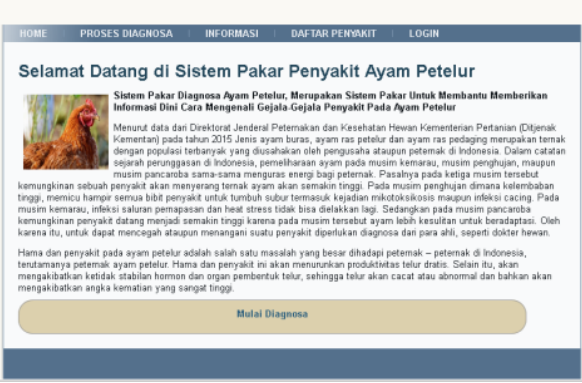

Gambar 4.2 Halaman Utama User.

Gambar 4.1 merupakan halaman utama pada admin yang berisi cara diagnose dan hasil diagnose dari penyakit ayam petelur

\subsection{Pengujian Manual Dengan Sistem}

Pada proses pertama pengguna menginputkan gejala baru dan di bandingkan dengan kasus lama yang ada di disistem dengan rumus sebagai berikut:, dan hasil dari sistem seperti Tabel 4.2.

Perhitungan Manual

$\frac{(1 * 1)+(0 * 1)+(0 * 1)+(0 * 3)+(0 * 3)+(0 * 3)+(1 * 3)+(0 * 5)}{1+1+1+3+3+3+3+5}$ $1+1+1+3+3+3+3+5$

$=0.2$ 
Perhitungan Sistem

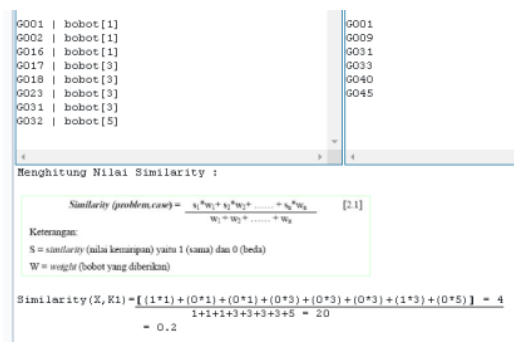

\subsection{Pengujian Error}

Hasil Pengujian error dilakukan perbandingan manual dengan system agar mengetahui hasil pengujian sistem dengan pengujian manual seperti langkah sebelumnya. Perbandingan nilai manual dan sistem pada Tabel 4.

\begin{tabular}{|c|c|c|c|}
\hline $\mathrm{N}_{0}$ & Perhitumgan Sistem & Perhitungan Manual & Selish Error \\
\hline 1 & 0.2 & 0.2 & $(0,2 \cdot 0.2)=0$ \\
\hline 2 & 0.41935483870968 & 0.41935483870968 & $\begin{array}{l}(0.41935483870968- \\
0.41935483870968)=0\end{array}$ \\
\hline 3 & 0.27272727272727 & 0.27272727272727 & $\begin{array}{l}(0.27272727272727- \\
0.27272727272727)=0\end{array}$ \\
\hline 4 & 0.23076923076923 & 0.23076923076923 & $\begin{array}{l}(0.23076923076923- \\
0.23076923076923)=0\end{array}$ \\
\hline 5 & 0.206896555172414 & 0.20689655172414 & $\begin{array}{l}(0.20689655172414- \\
0.206689655172414)=0\end{array}$ \\
\hline 6 & 0.3104347826087 & 0.3104347826087 & $\begin{array}{l}(0.3104347826087 . \\
0.3104347826087)=0\end{array}$ \\
\hline 7 & 0.33333333333333 & 0.33333333333333 & $\begin{array}{l}(0.33333333333333- \\
0.3333333333333)=0\end{array}$ \\
\hline 8 & 0.23076923076923 & 0.23076923076923 & $\begin{array}{l}(0.23076923076923 . \\
0.23076923076223)=0\end{array}$ \\
\hline TOTAL & 2.204285241 & 2.024285241 & 0 \\
\hline
\end{tabular}

\subsection{Pengujian Fungsionalitas Sistem}

Pengujian sistem merupakan proses menampilkan sistem dengan maksud untuk menemukan adanya kesalahan atau tidak pada sistem sebelum sistem dipublikasikan untuk digunakan oleh masyarakat. Penggujian dilakukan dengan menggunakan browser google chrome, Mozila Firefox dan Internet Explorer.

\begin{tabular}{|c|c|c|c|c|}
\hline \multirow[b]{2}{*}{ Alkses } & \multirow[b]{2}{*}{ Fungsi } & \multicolumn{3}{|c|}{ Browser } \\
\hline & & $\begin{array}{l}\text { Google } \\
\text { Chrome }\end{array}$ & $\begin{array}{l}\text { Mozila } \\
\text { Firefox }\end{array}$ & $\begin{array}{l}\text { Internet } \\
\text { Explorer }\end{array}$ \\
\hline \multirow{4}{*}{ Admin } & $\begin{array}{l}\text { Bisa mengakses halaman } \\
\text { admin untuk login. }\end{array}$ & $\checkmark$ & $\checkmark$ & $\checkmark$ \\
\hline & $\begin{array}{l}\text { Dapat melakukantambah, } \\
\text { edit, dan hapus data } \\
\text { penyakit. }\end{array}$ & $\checkmark$ & $\checkmark$ & $\checkmark$ \\
\hline & $\begin{array}{l}\text { Dapat tm elakukan tambah, } \\
\text { edit, dan hapus data gej ala. }\end{array}$ & $\checkmark$ & $\checkmark$ & $\checkmark$ \\
\hline & $\begin{array}{l}\text { Dapat melakukantambah, } \\
\text { edit, dan hapus data relas } \\
\end{array}$ & $\checkmark$ & $\checkmark$ & $\checkmark$ \\
\hline \multirow{3}{*}{ User } & $\begin{array}{l}\text { Dapat me elihat m enu home } \\
\text { user. }\end{array}$ & $\checkmark$ & $\checkmark$ & $\checkmark$ \\
\hline & $\begin{array}{l}\text { Dapat m elakukan proses } \\
\text { diagnosis konsultas } \\
\text { pakar. }\end{array}$ & $\checkmark$ & $\checkmark$ & $\checkmark$ \\
\hline & $\begin{array}{l}\text { Dapat melihat meru } \\
\text { tentang }\end{array}$ & $\checkmark$ & $\checkmark$ & $\checkmark$ \\
\hline
\end{tabular}

\subsection{Pengujian Kepuasan User}

Pada pengujian kepuasan terhadap calon pasien, pengujian dilakukan secara langsung diantaranya oleh calon pasien, kuisioner tersebut disebar kepada 16 orang calon pasien untuk mengetahui seberapa besar kepuasan pengguna terhadap aplikasi Sistem Pakar Diagnosis Penyakit Ayam Petelur menggunakan metode Case Base Reasoning. Hasil pengujian kepuasan pengguna ditunjukkan Tabel.

\begin{tabular}{|c|c|c|c|c|}
\hline \multirow{2}{*}{ Pertanbaan } & \multicolumn{4}{|c|}{ Jawahan } \\
\hline & SB & B & $\mathrm{C}$ & $\mathrm{K}$ \\
\hline $\begin{array}{l}\text { Adakah Bahas a yang dizunakan } \\
\text { pada tampilan pemilihan zejaladam } \\
\text { basild diagnose mordahdinahami? }\end{array}$ & 6 & 6 & 4 & - \\
\hline $\begin{array}{l}\text { Adakah naxizasi pemilihan zeiala } \\
\text { berras "check box" nuddath } \\
\text { dizunakan? }\end{array}$ & - & 10 & 6 & - \\
\hline $\begin{array}{l}\text { Anakah Laxizasi tombol proses } \\
\text { yntuk menchasilkan bumpulan } \\
\text { penxakit bisa anda pahami dam } \\
\text { dizunakan? }\end{array}$ & 4 & 4 & 8 & - \\
\hline 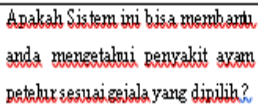 & 2 & 8 & 6 & - \\
\hline $\begin{array}{l}\text { Apakah perpaduan wama } \\
\text { background dan wama tylisanpada } \\
\text { sistem terlihat jelas pada } \\
\text { bandanganmatanda? }\end{array}$ & 3 & 8 & 5 & - \\
\hline JUMLAH & 15 & 36 & 29 & \\
\hline Paxentase & $18.75 \%$ & $45 \%$ & $36.25 \%$ & \\
\hline
\end{tabular}




\section{KESIMPULAN}

Berdasarkan hasil dari perancangan dan implementasi dari penelitian sistem pakar diagnosis penyakit ayam petelur menggunakan metode Case Base Reasoning maka dapat diambil beberapa kesimpulan yaitu :

1. Pada perbandingan pengujian perhitungan manual dengan sistem didapatkan selisih antara hasil selisih error manual dengan sistem adalah 0

2. Berdasarkan dari pengujian fungsionalitas sistem pakar diagnosis ayam petelur dengan google chrome, mozila firefox dan internet explorer berhasil dengan sebagai mana mestinya.

3. Pada pengujian kepuasan pengguna diambil hasil bahwa dari 16 pengguna yang telah diberi kuisioner memberikan nilai kepuasan dari segi penggunaan, tampilan antarmuka, manfaat, kelengkapan informasi aplikasi. Dari hasil pengujian didapatkan presentase sebanyak $15 \%$ pengguna menyatakan bahwa system Sangat Baik, 36\% menyatakan Baik dan 29\% menyatakan bahwa pengguna cukup setuju dengan sistem pakar diagnosis penyakit ayam petelur

\section{DAFTAR PUSTAKA}

[1] Mukhammad Shaid dkk "Sistem Pakar Pertumbuhan Balita Berbasis Web Menggunakan Metode Case Base Reasoning". ISSN: 2338-4018 2015. Jurnal TIKomSiN

[2] Rabiah Adawiyah "Case Base Reasoning Untuk Diagnosis Penyakit Demam Berdarah " Vol.1 No.1 Februari 2017. 2549-6824

[3] Tiara Eka Puti dkk "Implementasi Metode Case Base Reasoning Dalam Pemilihan Hama Pestisida Terhadap Hama Padi Sawah Menggunakan Algoritma KNN " Vol.4 No. 1 Maret 2016. Universitas Bengkulu

[4] Hengki Tamando "Sistem Pakar Mendiagnosa Penyakit Kolestrol Pada Remaja Dengan Metode Certinty Factor (CF) Berbasis Web". Vol 15 No 1 Juni 2014. STMIK Pelita Nusantara Medan.

[5] Kusumadewi, S. (2003). Artificial Intelligence (Teknik dan Aplikasinya). Yogyakarta: Graha Ilmu.

[6] Ashari, A., \& Muniar, A. Y. "Penerapan Sistem Pakar Untuk Mengidentifikasi Penyakit Pencernaan Dengan Pengobatan Cara Herbal". Jurnal Ilmu Komputer, 2(2), 24-30.2018. 